\title{
SARAJEVO-ROMANIJA REGION: A FLUID SPACE BETWEEN THE RURAL AND URBAN
}

\author{
Goran Mutabdzija ${ }^{1}$
}

Received 14 March 2016; Accepted 15 September 2016

\begin{abstract}
In this paper, emphasis is placed on the complexity of rural-urban relations and their reflection on the important socio-geographical processes, from de-agrarian and migration to the creation of new settlements and strengthening nodality individual centres. A clear polarization in urban and rural areas is more difficult due to the lack of adequate statistical indicators or deployment of institutions with different degree of importance, population density and distance from major city, providing sufficiently clear evidence of the degree of urbanity of local communities. This can be best seen in the Bosnia and Herzegovina $(\mathrm{BiH})$ which is sparsely populated country with an average of 74 inhabitants $/ \mathrm{km}^{2}$. Since there is a clear correlation between this indicator and sustainable development, increasing urbanization rates, which can stimulate economic growth and reduce poverty, is set as the primary social objective. Many developing countries looking for a way better governance of rural-urban relations, as one of the elements of inclusive growth, as a crucial element in the development of any society through innovation (industry) and harmonious territorial relations (urban-rural). Since $\mathrm{BiH}$ has a negative historical heritage but also unfavourable indicators of the degree of urbanization (40\%), macroeconomic stability ( $29 \%$ of the GDP of the EU average) and the degree of innovation ( $44 \%$ compared to Switzerland) it is clear that should be analyzed and rural-urban relations as one of the signposts along the way of creating a better and healthier society.
\end{abstract}

Keywords: Bosnia and Herzegovina $(\mathrm{BiH})$, Republic of Srpska (RS), East Sarajevo, urbanization, nodality, urban-rural relations.

Izvod: $\quad U$ ovom radu je stavljen akcenat na komplikovanost rualno-urbanih odnosa U Bosni i Hercegovini koja je rijetko naseljena zemlja sa prosječno $74 \mathrm{st} / \mathrm{km}^{2}$. Pored negativnog istorijskog naslijeđa, Bosna i Hercegovina ima nepovoljne pokazatelje o stepenu urbanizacije (40\%), makrekonomskoj stabilnosti (GDP 29\% prosjeka EU) i stepenu inovativnosti (44\% u odnosu na Švajcarsku). Cilj rada je pojašnjenje paralelnih procesa koji su se odigrali nakon završetka građanskog rata 1995 u Sarajevu i njegovoj okolini. Prvi proces je bila snažna migracija stanovništva iz Sarajeva u Republiku Srpsku (uglavnom Srbi) i obnuto, iz Republike Srpske u Sarajevo (uglavnom Bošnjaci). Drugi proces je nastanak novog grada Istočno Sarajevo (ekvivalent Sarajevsko-romanijska regija) u prostoru koji je do 1992. bila periferija Sarajeva. Treći proces pojašnjava karakter aktuelnih urbano-ruralnih procesa unutar Sarajevsko-romanijske regije. Jasna polarizacija na urbane i ruralne sredine je teža usljed nedostatka adekvatnih statističkih pokazatelja,

\footnotetext{
${ }^{1}$ Doc. Dr. Goran Mutabdzija, University of East Sarajevo, Faculty of Philosophy, Alekse Šantiča 1, 71420 Pale; e-mail: goran.mutabdzija@ffuis.edu.ba
} 
ali razmještaj institucija različitog stepena važnosti, gustina stanovanja i udaljenost od većeg grada, pruža dovoljno jasne dokaze o stepenu urbanosti pojedinih lokalnih zajednica.

Keywords: BiH, RS, Sarajevo-Romanija region, urbanization, nodality, urban-rural relations.

\section{Introduction}

Sarajevo-Romanija region is mesoregional unit within the Republic of Srpska (RS). By 1992 this region was part of the catchment area of Sarajevo ${ }^{2}$, which accounted for underdeveloped and sparsely populated municipality in which they dominated the forestry, agricultural and machine industry. In this highland area population of around 74,000 people (an average of 35 inhabitants $/ \mathrm{km}^{2}$ ), and the specificity of the region is reflected in the strong nodal-functional transformation of space, composed after the civil war in ex-Yugoslavia 1992-95.

During the last 25 years, the example of the region can be observed dynamic and often opposing processes: the demographic (migration, depopulation, aging), the transformation of settlements (urbanization and strengthening nodality) redesigning administrative boundaries (establishment of new municipalities and the formation of East Sarajevo ${ }^{3}$ ) and restructuring Economy (tertiarization). By 1991 within this region were in the municipality of Pale, Sokolac and Rogatica, and other municipalities: Istočna Ilidža, Istočno Novo Sarajevo, Istočni Stari Grad and Trnovo are divided municipalities ${ }^{4}$, which are made by the Dayton Peace Agreement. For the purpose of comparability of data for the divided municipality, the data of 1991 are presented only for the part of the municipality that has entered into the Republic of Serbian in 1995.

Tab 1. General geographical data about the municipalities of the Sarajevo-Romanija region.

\begin{tabular}{|c|c|c|c|c|c|c|c|c|c|}
\hline \multirow{2}{*}{ No. } & \multirow{2}{*}{ Municipality } & \multirow{2}{*}{$\begin{array}{c}\text { Altitude } \\
\mathrm{m}\end{array}$} & \multirow{2}{*}{$\begin{array}{l}\text { Area } \\
\mathrm{km}^{2}\end{array}$} & \multicolumn{4}{|c|}{ Number of inhabitants } & \multirow{2}{*}{$\begin{array}{c}\text { Density } \\
2013\end{array}$} & \multirow{2}{*}{$\begin{array}{c}\text { Index } \\
2013 / 91\end{array}$} \\
\hline & & & & 1991 & 1996* & $2004^{*}$ & 2013 & & \\
\hline 1 & Istočna Ilidža & 530 & 27 & 7840 & 16403 & 16754 & 15233 & 564 & 194 \\
\hline 2 & Ist. Novo Sarajevo & 540 & 36 & 4197 & 8928 & 9129 & 11477 & 319 & 273 \\
\hline 3 & Pale & 850 & 490 & 16355 & 26391 & 26959 & 22282 & 45 & 136 \\
\hline 4 & Ist. Stari Grad & 1050 & 76 & 1887 & 3100 & 3185 & 1175 & 15 & 62 \\
\hline 5 & Sokolac & 878 & 759 & 14883 & 17081 & 17449 & 12607 & 17 & 85 \\
\hline 6 & Rogatica & 539 & 640 & 21978 & 13699 & 14850 & 11603 & 18 & 53 \\
\hline 7 & Trnovo & 823 & 113 & 6991 & 2145 & 2594 & 2192 & 19 & 31 \\
\hline
\end{tabular}

Source: $h$ ttp://www.rzs.rs.ba ${ }^{*}{ }^{*}$ estimate number of inhabitants by Institute for Statistics)

Looking at the previous table, it appears that there were no major changes in relation to 1991 2013 , because the population of the region is almost the same (up 3.2\%), but in fact, there have been huge changes that have fundamentally changed the demographic and social picture of Sarajevo ${ }^{5}$ and the Sarajevo-Romanija region: spatial, economic, social, professional, ethnic. Therefore, the hypothesis of work can be presented as:

- In terms of increased globalization, lack of urban facilities and economic activity leads to a weakening of nodal-functional links within the region, economic stagnation and the process of depopulation of rural areas.

\footnotetext{
${ }^{2}$ City of Sarajevo in 1991 consisted of 10 municipalities with 527,049 inhabitants (A Muslim-Bosniaks 49.2\%, 29.8\% Serbs, $6.6 \%$ Croats, $10.7 \%$ Yugoslavs and 3.6\% other), which had divided during the city war (Serbian and Muslim parts). The Dayton peace agreement in 1995 has stopped the war and reunites the city, but due to that fact, dissatisfied residents Serbian part of the city had decided to leave Sarajevo and went to the Republic of Srpska, Yugoslavia or a third country.

${ }^{3}$ City of East Sarajevo has formed in 1993, consisting of 7 municipalities and territorially coincides with the area of the Sarajevo-Romanija region.

${ }^{4}$ IEBL (Inter Entity Border Line) was formed in Dayton (Ohio, USA) and is not consistent with municipality's borders and as a result, create new municipalities across $\mathrm{BiH}$.

${ }^{5}$ According to the census of 2013 , Sarajevo has 438,433 inhabitants and census results are not yet official because of disagreements of entity's statistical Institutes on the number of resident persons.
} 
- Strengthening of educational and health institutions and the economy, is the most effective measure to increase the urbanity of the entire region, which has a positive effect on increasing cohesion within the region and reducing the negative impacts of globalization.

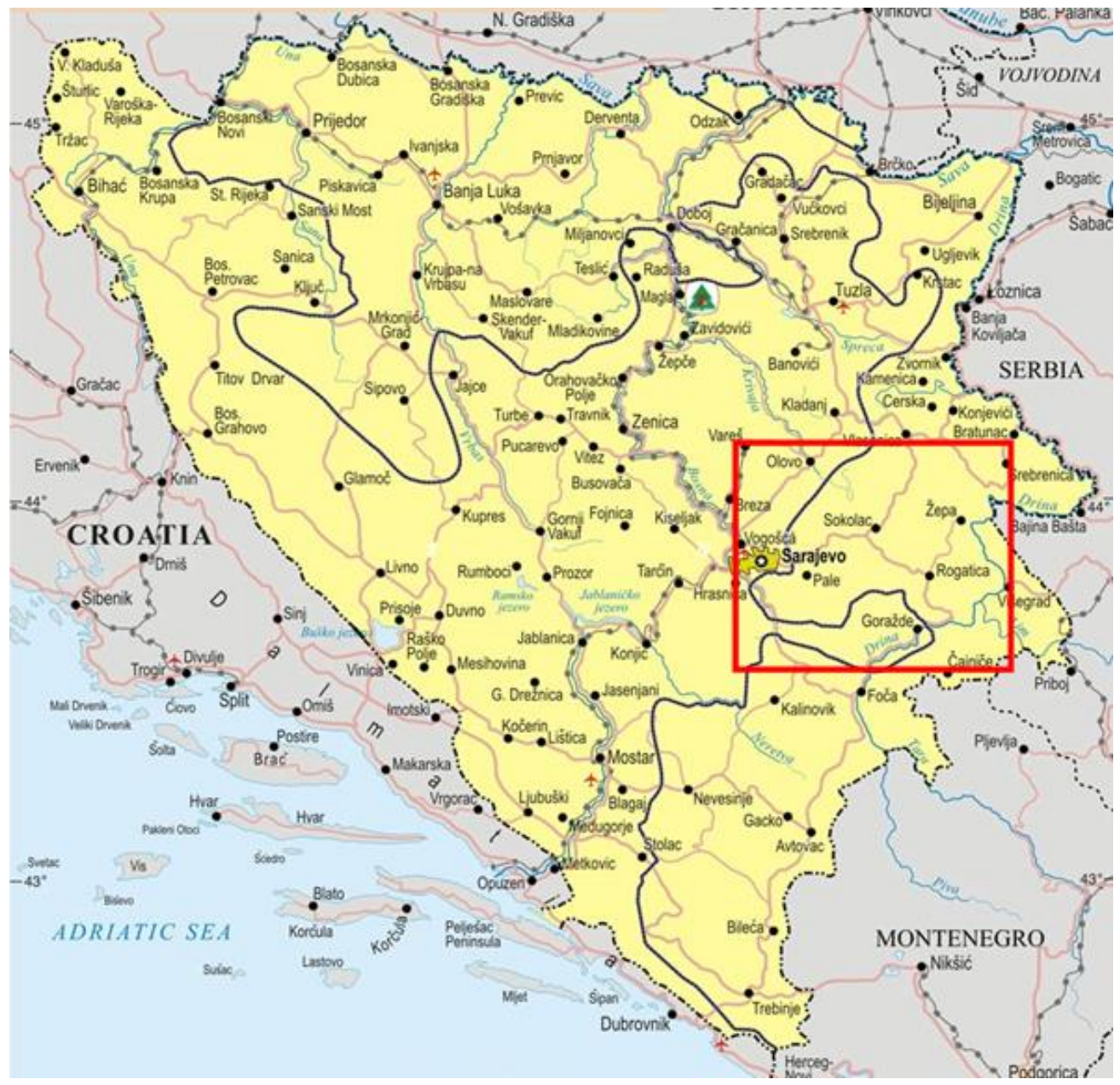

Fig 1. The area under study.

\section{Urban-rural narrative}

In the context of delimitation of rural areas, population density is shown as a basic element of urbanity of an area, and is based on the first generally accepted methodology for delimitation of rural areas developed by the OECD (1994). Classification was carried out on urban, transitional and rural areas according to the share of the population of a region living in rural local units, which are defined as local administrative units with a population density below 150 inhabitants $/ \mathrm{km}^{2}$. ESPON (2004) on the basis of urban influence and human intervention defined European typology of urban-rural relations in order to provide a better understanding of the diversity of European regions. The developed typology is based on the idea of two main dimensions, the degree of urban influence and the degree of human intervention. Two classes of urban influence and the three classes of human intervention are combined in six different types in which the main division into two classes of urban influence (high and low) and three classes according to the intensity of human intervention (high, medium and low). Dijkstra and Poelman (2008) defined a new typology of using the OECD classification in combination with a distance of residence from the nearest town. This new approach combines the time spent in travelling to the nearest town, which implies that at least $50 \%$ of the population lives at a distance closer than 45 min drive to the city of $>50,000$ inhabitants. 
Significant improvement in the field of delimitation of these areas is the work of researchers Joint Research Centre, which introduced two new indices: peripherality ${ }^{6}$ and land cover criterion ${ }^{7}$. As an indicator of peripherality, the travel time by road network to urban centres has been selected, including speed limits for different road categories and impedance two factors: a congestion index and a slope index. The land cover criterion to assess the "natural" (no artificial) character of the local units, the threshold of $75 \%$ has been chosen: a commune is classified as an "open space" commune if at least $75 \%$ of its area is covered by forest, agricultural or natural areas. Otherwise, the commune is characterized as "closed space". Finally, the peripherality and the land cover indicators were integrated in the OECD methodology, creating four classes of local units, "rural-peripheral", "rural-accessible", "urban open-space" and "urban-closed space." (Jonard et al. 2009: 4-8).

Based on the "Grand narrative", ESPON Edora (2010) has developed a new typology of urban and rural areas, which is an elaboration of the typology Dijkstra-Poelman urban-rural classification, as a series of rural socio-economic environment, which act as starting points for the highly differentiated changes. Typology has a relatively simple hierarchical and multicriteria approach, in which rural regions are separated from the first urban, then on the basis of participation "exhausted" and "accumulative" units mainly primary sector, carried out the separation of the agricultural regions, which are then classified into "semi-subsistence", "semiproductive" and "para-productive". Further diversification, the regions are classified as "New rural economy" and "Less Fords'" regions. Following the European Spatial Development Programme (ESDP), the European study program proposed number of 150 inhabitants $/ \mathrm{km}^{2}$, as the lower limit of urbanity some territories. (Mutabdzija 2016: 123)

\section{Physiognomic structure of the Sarajevo-Romanija region}

Urbanization is a universal process that is based on interdependent factors: an increased proportion of the urban population, the process of de-agrarianism rural population and the spread of urban lifestyles. These factors are a synthesis of spatial and social characteristics of urbanization, which can be expressed as a very dynamic of settlement-geographical and socioeconomic process, which leads to the transformation of the geographical environment. Due to physical-geographic, socio-geographic and historical-political factors, the process of urbanization can be seen in three basic components: demographic, physiognomic and functional. This process is imminent cities and their surroundings and its development is characterized by four basic stages: concentration, sub-urbanization, de-urbanization and re-urbanization. Besides the uneven concentration of the population in all centres of growth-development and sporadic suburbanization former mountains resorts at Jahorina, Trebevic and Romanija, the other phases of urbanization in the Sarajevo-Romanija region not represented. These can be identified only two nodal centre Pale and Istočna llidža-Istočno Novo Sarajevo. In these cities, the urbanization phase did not go in succession, but were partially matched because of strong historical and political factors (unfortunately the civil war) and the consequences of which he passed. These centres continuously recorded growth of population and to elements of the current density housing and possibilities of spatial expansion are close to their optimum. This is evident by their impact on other settlements within municipalities that gravitate.

Based on analysis of the structure of land fund and using CORINE methodology, it is evident that the greatest expanse occupying "forest (52.54\%), agricultural land-III group (33.97\%), group II $(9.13 \%)$, group I (3.41\%) and the barren land-cities $(0.96 \%)$. This analysis should be joined by the analysis of hypsometric relations, which can range from $290 \mathrm{~m}$ to $1900 \mathrm{~m}$, in order to improve the consideration of physiognomic structure of the region. Lands to $500 \mathrm{~m}$ occupy only $1 \%$ of the total area of the region, terrain height of $500-800 \mathrm{~m} 17 \%$, terrain from 800 to $1200 \mathrm{~m} 66 \%$, and terrain over $1200 \mathrm{~m} \mathrm{16 \%}$. The average altitude of the region is $990 \mathrm{m"}$ (PP IS 2004: 59-78). Although this spatial plan of Istočno Sarajevo was made in 2004 and in the past has been done

\footnotetext{
6 The ArcGIS 9.2 (ESRI) software extension "Network Analyst" is used to process the peripherality analysis. This extension allows network-based spatial analysis including "routing", "origin destination cost matrix" and "service area" analysis.

${ }^{7}$ On the bases CORINE (Coordination of Information on the Environment)
} 
on the construction of new settlements, roads, etc., but It is clear that it makes only $1 \%$ of the area of the region. It should be added that the central parts of the two municipalities, Istočna llidža and Istočno Novo Sarajevo, brand new urban settlements that have grown together and form a unique architectural and urban whole, which was formed after 1996 and represents the European framework recent example of primary urbanization (the emergence of new centre).

Fig 2. Structure of agricultural land (Corine) and the deployment of municipal centres in the Sarajevo-Romanija region.

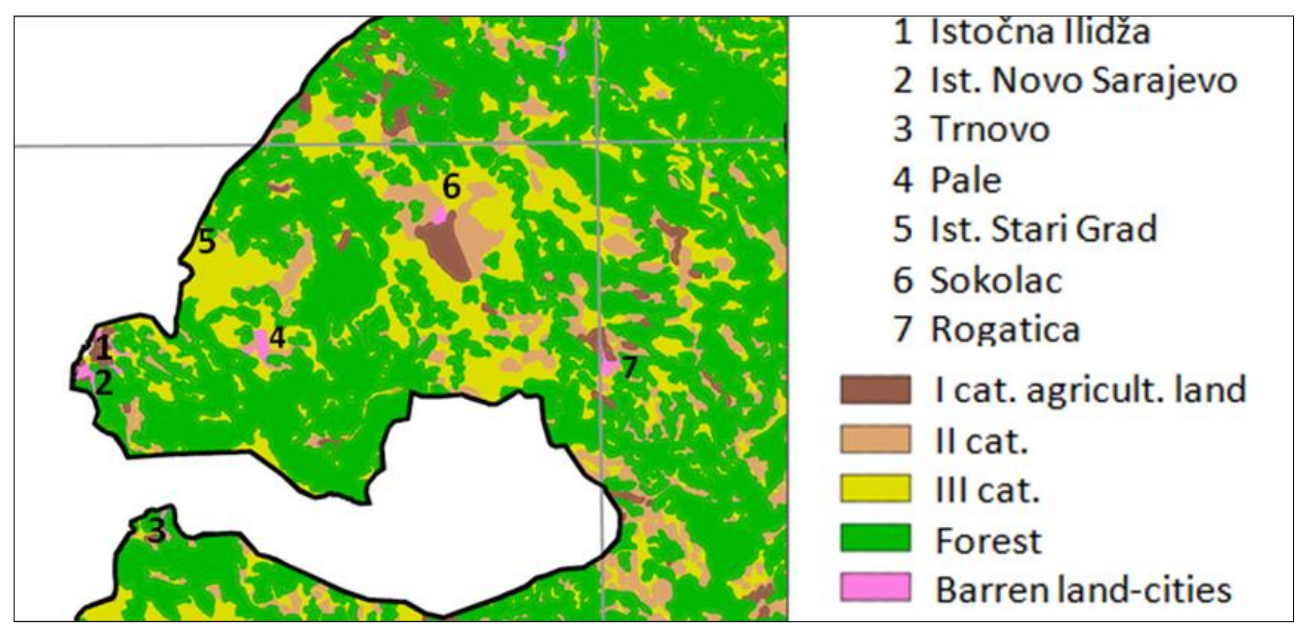

Source: Based on the Spatial Plan of the Republic of Srpska (clip M1:1,200,000)

Based on these indicators on physiognomic structure of the region, it was clear that without increased urbanization process will not be achieved sustainable operational structure of regions and that this will lead to rapid depopulation.

\section{Functional structure of the Sarajevo-Romanija region}

The new administrative and political relations within $\mathrm{BiH}$, led to a new functional structure of the region, which remained without a central nodal-functional centre and only a city. Establishing Kasindo Hospital (previously a sanatorium) was the first decision that is functional introduced a hierarchy within a single segment of society (health). This was followed by the establishment of the University of Istočno Sarajevo, whose 16 faculties located in a wide area of Republic of Srpska from Trebinje, (South), Pale (centre), Bijeljina (north) to Doboj (west). Within the SarajevoRomanija region is located 8 faculties in the two centres'. In Pale formed Philosophy, Law, Economics, and the Faculty of Sport and in Istočno Novo Sarajevo, Electrical Engineering, Mechanical Engineering, Agricultural and Music Academy. In addition to Electro Engineering, all institutions were created to new locations and with the teaching staff who previously worked at the University of Sarajevo. This process was followed by the formation of the University and other institutions, from the library, radio-TV stations to the centres of culture. The third important element in strengthening the functional structure of the region is to activate the tourist centre Jahorina, which in 1984 held XIV Winter Olympic Games. A clearer picture of the functional structure of the region can be acquired through analysis and evaluation of certain functions: 
Tab 2. Types of institutions of the state level (BiH), republic (RS), regional and local importance in the region.

\begin{tabular}{|c|c|c|c|c|c|c|}
\hline \multirow{2}{*}{ No. } & \multirow{2}{*}{$\begin{array}{l}\text { Centre of } \\
\text { Municipality }\end{array}$} & \multirow{2}{*}{ Centrality } & \multicolumn{4}{|c|}{ Functions of settlements and importance of Institutions } \\
\hline & & & $\mathrm{BiH}$ & RS & Regional & Local \\
\hline 1 & Istocna llidza & Yes & $\begin{array}{l}\text { Central prison, } \\
\text { Institute }\end{array}$ & $\begin{array}{l}\text { Detachment of } \\
\text { Government, } \\
\text { Economic Court }\end{array}$ & $\begin{array}{l}\text { Hospital, } \\
\text { Prison }\end{array}$ & $\begin{array}{l}3 \text { Primary schools, Secondary school, } \\
\text { Sports hall, Cultural centre, Theatre, } \\
3 \text { Hotels, Radio station, } 3 \text { Shopping } \\
\text { malls }\end{array}$ \\
\hline 2 & $\begin{array}{l}\text { Istocno Novo } \\
\text { Sarajevo }\end{array}$ & Yes & $\begin{array}{l}\text { Security } \\
\text { agency, } \\
2 \text { Directorates }\end{array}$ & 2 Directorates & $\begin{array}{l}\text { Rectorate, } \\
4 \text { Faculties, } \\
\text { Prosecution, } \\
\text { TV station }\end{array}$ & $\begin{array}{l}\text { Primary school, Gymnasium, Music } \\
\text { school, Sports hall, Ambulance, } \\
3 \text { Hotels }\end{array}$ \\
\hline 3 & Pale & Yes & & 2 Directorates & 4 Faculties & $\begin{array}{l}2 \text { Primary schools, } 2 \text { Secondary } \\
\text { schools, Sports hall, Cultural centre, } \\
\text { Ambulance, } 2 \text { Hotels, } 2 \text { Shopping malls }\end{array}$ \\
\hline 4 & Sokolac & Yes & & $\begin{array}{l}\text { Head of Forestry, } \\
\text { Psychiatric hospital }\end{array}$ & Court & $\begin{array}{l}\text { Primary and Secondary schools, Sports } \\
\text { hall, Cultural centre, Ambulance, Hotel }\end{array}$ \\
\hline 5 & Rogatica & No & & & & $\begin{array}{l}\text { Primary and Secondary schools, } \\
\text { Cultural centre, Ambulance, Hotel }\end{array}$ \\
\hline 6 & Trnovo & No & & & & $\begin{array}{l}\text { Primary school, Cultural centre, } \\
\text { Ambulance }\end{array}$ \\
\hline 7 & $\begin{array}{l}\text { Istocni Stari } \\
\text { Grad }\end{array}$ & No & & & & Ambulance \\
\hline
\end{tabular}

The above table shows that the greatest concentration of institutions in the municipal centres of Istocna (East) Ilidža-Istocno Novo Sarajevo and Pale and that the two nodal centres, $25 \mathrm{~km}$ away from each other, with divided responsibilities and expressed complementarily. Since this region is leaning on the city of Sarajevo, he remains a powerful centre of gravity and the region, but predominantly in the field of labour, trade and cultural events.

\section{Concluding remarks}

The example of the Sarajevo-Romanija region is visible unscrewing three parallel processes that took place throughout Bosnia and Herzegovina at the end of $20^{\text {th }}$ century. The first process is characterized by a strong migration of the population, mainly rural to urban areas and had the ethnic dimension. For example, in this region is visible and the movement of population in the opposite direction-from city to villages. The second process is marked by the creation of new administrative units, as a result of new concentrations of population in divided municipalities (according Inter entity boarder line). Using the example of this region, there are municipalities Istocna llidza, Istocno Novo Sarajevo and Istocni Stari Grad. The third process is visible as a clear correlation between increasing degree of urbanity within the Sarajevo-Romanija region and improving demographic and nodal-functional characteristics of the region. A specific problem is represented an attempt to stop the emigration of urban population of Sarajevo in the hilly and mountainous, economically underdeveloped and predominantly rural areas. In the absence of basic urban facilities and institutions, in terms of a very low standard of living and the emotional stress he wore every individual who has survived a civil war, began the process of creating a new city. The establishment of educational, cultural and health institutions have proved to be a good model to create centres with increased concentration of population, as a precondition for future growth $^{8}$ and development. Based on the present, there are three different zones within this region: predominantly urban, transition from rural to urban and predominantly rural type of local communities.

Space municipalities Istocna llidza - Istocno Novo Sarajevo is an example of a typical urban community which is characterized by compact urban-housing with a density of 424 inhabitants $/ \mathrm{km}^{2}$, a concentration of $35 \%$ of the population of the region, average

${ }^{8}$ OECD def. "Economic growth that creates opportunity for all segments of the population and distributes the dividends of increased prosperity, both in monetary and non-monetary terms, fairly across society" 
altitude $<600 \mathrm{~m}$, near Sarajevo, the existence of institutions with different degree of importance and numerous other service sectors. The municipality of Pale is the second unit dominated by mountainous terrain, the average altitude is $>900 \mathrm{~m}$, the municipality has $29 \%$ of the population of the region was developed network of settlements where municipal centre is dominated by all elements of the spatial structure. The presence of institutions of national and regional significance and proximity to Sarajevo $(22 \mathrm{~km})$ enhances nodality this centre, but a small population density (45 inhabitants $/ \mathrm{km}^{2}$ ) puts the municipality in a transition type. The rest of the region includes four underdeveloped municipalities with a predominantly mountainous terrain (average altitude > $1000 \mathrm{~m}$ ) in which $36 \%$ of the population lives in the region with an average density 17 inhabitants $/ \mathrm{km}^{2}$. It is clear that this area has predominantly rural characteristics.

Based on the presented indicators, the Sarajevo-Romanija region represents less fluid space between urban and rural, and more space that has a vision for future development. The level of development in this area over the last two decades was dynamic and was able to mitigate the negative effects of the recent past through a parallel process of concentration of population and institution building. The intensity of urbanization cascade and proportionally decreases with distance from Sarajevo, which is visible through the existence of three different zones, which gives the entire region features transitional urban-rural units. In this way, the work confirmed the hypothesis according to which the lack of urban facilities and economic activity leads to a weakening of nodal-functional links within the region, economic stagnation and the process of depopulation of rural areas (Sokolac, Rogatica, Istocni Stari Grad and Trnovo) but also to strengthen education and health institutions and businesses, the most effective measure to increase the urbanity of the entire region, which has a positive effect on increasing cohesion within the region (Istocna llidza, Istocno Novo Sarajevo and Pale).

References

[1] Bengs, Ch. \& Schmidt-Thomé, K., eds. (2004). Urban-rural relations in Europe. ESPON: Luxembourg.

[2] Böhme, K., Hague, C., Toptsidou, M., Gløersen, E. \& Holstein, F. (2014). Territories finding a New Momentum: Evidence for Policy Development, Growth and Investment [third ESPON synthesis report]. ESPON: Luxembourg.

[3] Bontje, M., Musterd, S. \& Pelzer, P. (2011). Inventive City-Regions. Path Dependence and Creative Knowledge Strategies. Farnham: Ashgate.

[4] Copus, A. \& Hörström, L., eds. (2012). The New Rural Europe: Towards Rural Cohesion Policy [Research report]. Stockholm: NORDREGIO.

[5] Dijkstra, L. \& Poelman, H. (2012). Cities in Europe-the new OECD-EC definition. EU-DG Regio.

[6] Dijkstra, L. \& Poelman, H. (2014). A Harmonised definition of cities and rural areas: the new degree of urbanisation. EC DG Regio, WP 01/2014.

[7] Dudwick, N., Hull, K., Katayama, R., Shilpi, F. \& Simler, K. (2011). From Farm to Firm, RuralUrban Transition in Developing Countries. Washington, DC: World Bank.

[8] Đorđević, D. (1996). Prostorno planiranje-ključna oblast aplikativne geografije? Glasnik geografskog društva Republike Srpske 76(1).

[9] Harris, J. M. (2000). Basic Principles of Sustainable Development. Medford MA: Tufts University.

[10] Hudson, R. (2005). Region and place: Devolved regional government and regional economic success? Progress in Human Geography 29(5), 618-625. Doi: 10.1191/0309132505ph572pr. 
[11] Jonard, F., Lambotte, M., Ramos, F., Terres, J. M. \& Bamps, C. (2009). Delimitations of rural areas in Europe using criteria of population density, remoteness and land cover. Ispra: EC Joint Research Centre.

[12] Lorentzen, A. \& Jeannerat, H. (2012). Urban and regional studies in the experience economy: What kind of turn? European Urban and Regional Studies 20(4), 363-369. Doi: $10.1177 / 0969776412470787$.

[13] Mutabdzija, G. (2011). Republic of Srpska in the process of the NUTS standardization, Conference "Cohesion Policy: What Future For Cohesion Policy? An Academic Policy Debate, Bled: DG Regio - Government of Slovenia-RSA.

[14] Mutabdzija, G. (2013). Republic of Srpska: Socio-Geographic Challenges. Analele Stiintifice ale Universitatii "Al. I. Cuza" din lasi. Serie Noua. Geografie 59(1), 209-219.

[15] Mutabdzija, G. (2016). Evropski izazovi-od geografskih ka inovativnim regijam. Istočno Sarajevo: Zavod za udžbenike i nastavna sredstva.

[16] Ulied, A., Biosca, O. \& Rodrigo, R. (2010). Urban and rural narratives and spatial development trends: State of the Question [Research report]. Barcelona: Mcrit SL.

[17] Urbanistički zavod RS (2004). Prostorni plan grada Istočno Sarajevo do 2015, Banja Luka.

[18] Urbanistički zavod RS (2009). Prostorni plan Republike Srpske do 2020, Banja Luka.

[19] Woods, M. \& McDonagh, J. (2011). Rural Europe and the World: globalization and rural development. European Countryside 3(3), 153-163. Doi: 10.2478/v10091-012-0001-z. 